\title{
Unified agricultural tax as an indicator of the dynamics of agricultural development in the Russian Federation
}

\author{
Elena Sivolapenko ${ }^{1 *}$, Ekaterina Sapozhnikova ${ }^{2}$, and Olga Tyutyunik ${ }^{3}$ \\ ${ }^{1}$ Don State Technical University, 1, Gagarin sq., 1, 344003, Rostov-on-Don, Russia
}

\begin{abstract}
Taxation of the agricultural sector continues to be one of the main directions of development of the tax policy of the Russian Federation. On the one hand, taxes in agriculture perform to a greater extent a stimulating function, being the main economic instrument of state regulation of the country's agro-industrial complex. On the other hand, the rate of development of the agricultural sector and the amount of tax revenues from the payment of unified agricultural tax to the consolidated budget of the state in relation to revenues from other special tax regimes tell us about the insufficient efficiency and popularity of this special tax regime and, consequently, about the presence of some problems of its legislative regulation
\end{abstract}

\section{Introduction}

Agriculture for the Russian economy is one of the basic industries. With its help, the food security of the country is ensured, the needs of the population in food are satisfied. At the same time, the efficiency of organizing agricultural production depends not only on the efforts of commodity producers, but is also determined by climatic conditions that cannot be predicted. In this regard, there is a need for state support for agricultural producers, which is carried out, among other things, with the help of tax levers.

Today, the tax system of the Russian Federation is represented by five special tax regimes, which include:

1. Taxation system for agricultural producers (unified agricultural tax);

2. Simplified taxation system (STS);

3. The system of taxation in the implementation of production sharing agreements;

4. Patent taxation system;

5. Tax on professional income.

The effect of these special tax regimes is regulated by the Tax Code of the Russian Federation (Part 1,2) and individual federal laws [1,2].

The taxation system for agricultural producers (unified agricultural tax) (UAT) is a special tax regime that has been developed and introduced specifically for agricultural producers.

*Corresponding author : vladimirovnale95@mail.ru 


\section{Materials and methods}

The unified agricultural tax was introduced into the Russian taxation system in 2001 and began to be applied by agricultural producers from January 1, 2002 [5]. Prior to this period, Russian legislation provided only separate benefits for agricultural producers.

Initially, the idea of introducing this special tax regime pursued 2 goals: on the one hand, to ensure an increase in the efficiency of agricultural production by simplifying the taxation procedure for agricultural producers, on the other hand, to clearly link the amount of taxes paid to agricultural producers with the object and quality of land resources used in economic activity.

At the same time, the practical application of this tax regime in the first years of its existence did not show the expected results due to the presence of internal contradictions in the federal law and the use of various criteria, which in turn prevented the introduction of this regime on the territory of most constituent entities of the Russian Federation. It should be noted that initially this tax regime was introduced only by the laws of the constituent entities of the Russian Federation on this tax. In the first two years, this tax was introduced on their territory by only two constituent entities of the Federation (Krasnodar Territory and Altai Territory).

The main disadvantage of the new introduced special tax regime was that it could only be applied by agricultural producers engaged in the production of crop products. At the same time, the law did not allow transferring other agricultural producers involved, for example, in the production of livestock, fish products, diversified farms and complexes, to pay this tax.

The procedure for determining the size of the tax rate established by the Tax Code was very complicated due to the presence of a rather complicated scheme for approving the tax rate and its linking to the cadastral value of a hectare of agricultural land. A particular difficulty was created by the fact that for two years of the law's operation, the land cadastre had not been approved $[3,4,5]$.

Another disadvantage of the introduction of this regime was that the tax period for the fulfillment of the tax obligation was a quarter, not a calendar year, which created certain difficulties in the transition of most agricultural producers to this tax regime. This problem was caused by the seasonality of crop production and, as a consequence, the lack of financial resources from taxpayers in the first half of the year.

The above contradictions caused fundamental changes introduced by the legislator to the concept of the taxation system for agricultural producers, aiming it primarily at eliminating the identified shortcomings [6,7].

This required a clear definition of the criteria for attribution and the status of taxpayers for agricultural producers in various sectors of agriculture. In addition, it was necessary to introduce the most important elements of taxation commensurate for different farms, including such as the object of taxation, tax base, tax rate, which would ensure the observance of the principle of equality in taxation.

In this regard, at the end of 2003, a new law was adopted and in 2004 entered into force (from 11.11.2003 No. 147-FZ), which fundamentally changed the entire concept of a single agricultural tax established by Ch. 26.1 of the Tax Code of the Russian Federation.

The main advantages of the new taxation system for agricultural producers include the following amendments to the legislation of the Russian Federation:

- starting in 2004, the transition to this special tax regime began to be carried out on a voluntary basis. An organization that plans to switch to this special tax regime must submit a notification to the tax authority about the application of the regime before the onset of a 
new tax period (for operating organizations) and within 30 days from the date of registration for newly created organizations;

- in order to comply with the principle of equality of taxation, to ensure a unified approach for all economic entities, the range of organizations entitled to apply this special tax regime has been expanded. Now all organizations of the agro-industrial complex could switch to it, including agricultural organizations of the so-called industrial type, multidisciplinary organizations, as well as organizations engaged in the production of agricultural products, including fish products.

- in 2005, additional amendments were made to the Tax Code of the Russian Federation, according to which, starting in 2006, this special tax regime could also be used by Russian fishery organizations.

Today, in accordance with Art. 17 of the Tax Code of the Russian Federation, the legislator established the following mandatory elements of the "Unified Agricultural Tax", enshrined in Ch. 26.1 of the Tax Code (Table 1).

Table 1. Mandatory elements of the "Unified Agricultural Tax" (UAT).

\begin{tabular}{|c|c|c|c|}
\hline No & $\begin{array}{c}\text { Elements of } \\
\text { taxation }\end{array}$ & Values & Base \\
\hline 1 & Taxpayers & $\begin{array}{l}\text { Organizations and individual entrepreneurs that are agricultural } \\
\text { producers and transferred to the payment of unified agricultural tax }\end{array}$ & $\begin{array}{l}\text { Clause } 1 \text { of Art. } 346.2 \text { of the Tax Code of the } \\
\text { Russian Federation }\end{array}$ \\
\hline 2 & $\begin{array}{c}\text { Object of } \\
\text { taxation }\end{array}$ & Income reduced by the amount of expenses & $\begin{array}{l}\text { Art. } 346.4 \text { of the Tax Code of the Russian } \\
\text { Federation }\end{array}$ \\
\hline 3 & Tax base & Monetary value of income reduced by the amount of expenses & $\begin{array}{l}\text { Clause } 1 \text { of Art. } 346.6 \text { of the Tax Code of the } \\
\text { Russian Federation }\end{array}$ \\
\hline 4 & Tax period & $\begin{array}{l}\text { Calendar year. } \\
\text { The reporting period has also been set - half a year. }\end{array}$ & $\begin{array}{l}\text { Clause } 1 \text { of Art. } 346.7 \text { of the Tax Code of the } \\
\text { Russian Federation }\end{array}$ \\
\hline 5 & Tax rate & $\begin{array}{l}6 \% \text {, however, the laws of the constituent entities of the Russian } \\
\text { Federation may establish differentiated tax rates ranging from } 0 \text { to } \\
6 \% \text { for all or certain categories of taxpayers, depending on: } \\
\text { - from the types of agricultural products produced, as well as works } \\
\text { and services specified in Art. } 346.2 \text { of the Tax Code of the Russian } \\
\text { Federation; } \\
\text { - from the amount of income from the sale of agricultural products, } \\
\text { including products of its primary processing, produced from } \\
\text { agricultural raw materials of own production, as well as from the } \\
\text { performance of work and the provision of services specified in Art. } \\
346.2 \text { of the Tax Code of the Russian Federation; } \\
\text { - from the place of business; } \\
\text { - from the average number of employees }\end{array}$ & $\begin{array}{l}\text { Art. } 346.8 \text { of the Tax Code of the Russian } \\
\text { Federation } \\
\text { Art. } 346.2 \text { of the Tax Code of the Russian } \\
\text { Federation; }\end{array}$ \\
\hline 6 & $\begin{array}{l}\text { The procedure } \\
\text { for calculating } \\
\text { tax. }\end{array}$ & $\begin{array}{l}\text { The percentage of the tax base corresponding to the tax rate. The } \\
\text { procedure for calculating advance payments is also provided }\end{array}$ & $\begin{array}{l}\text { Clause } 1 \text { of Art. } 346.9 \text { of the Tax Code of the } \\
\text { Russian Federation }\end{array}$ \\
\hline 7 & $\begin{array}{l}\text { Procedure and } \\
\text { terms of tax } \\
\text { payment }\end{array}$ & $\begin{array}{l}\text { Terms of tax payment: } \\
\text { - not later than March } 31 \text { of the year following the expired tax } \\
\text { period; } \\
\text { - in case of termination of entrepreneurial activity, in respect of } \\
\text { which the UAT was applied - no later than the } 25 \text { th day of the next } \\
\text { month. } \\
\text { - separate deadlines have been set for advance payments. }\end{array}$ & $\begin{array}{l}\text { Clause } 5 \text { of Art. } 346.9 \text { of the Tax Code of the } \\
\text { Russian Federation, } \\
\text { Clause } 2 \text { of Art. } 346.10 \text { of the Tax Code of } \\
\text { the Russian Federation }\end{array}$ \\
\hline
\end{tabular}

The main advantage of this special tax regime is the payment of a single tax for agricultural producers, instead of several provided for by the general tax regime. Thus, organizations that have switched to the Unified Agricultural Tax are exempt from paying income tax and corporate property tax, individual entrepreneurs are exempt from paying personal income tax and property tax of individuals. It is worth noting that until December 31, 2018, organizations and individual entrepreneurs who switched to this regime were also exempted from VAT, however, this condition was not always beneficial to agricultural producers, since, not being VAT payers, they could not take advantage of the VAT tax deduction.

Starting from 2019, the legislator has made amendments to exclude the possibility of exemption from the payment of value added tax (VAT) for agricultural producers, applying the special tax regime "Unified Agricultural Tax". However, on the basis of the second paragraph of clause 1 of Art. 145 of the Tax Code of the Russian Federation, the legislator left for certain categories of taxpayers the unified agricultural tax the right to exemption from the duties of a taxpayer of VAT, provided that they transfer to the payment of the 
unified agricultural tax and exercise the right to exemption in the same calendar year or provided that for the previous tax period under the unified agricultural tax the amount of income from sales by types of activities in respect of which the unified agricultural tax is applied, excluding VAT, did not exceed in aggregate: 100 million rubles for 2018, 90 million rubles for 2019, 80 million rubles for 2020, 70 million rubles for 2021, 60 million rubles for 2022 and subsequent years.

It is worth noting a number of the following conditions for the application of the special tax regime "Unified Agricultural Tax" for agricultural producers:

1. Organizations (individual entrepreneurs) that do not produce agricultural products, but only carry out its primary or subsequent (industrial) processing, are not entitled to apply this regime.

2. If an organization (individual entrepreneur) is already operating and applies a general tax regime or a simplified taxation system, then she (he) can switch to the Unified Agricultural Tax only from the beginning of the next calendar year.

3. Agricultural producers that provide agricultural services to agricultural producers in the field of crop and livestock production are entitled to switch to the payment of the unified agricultural tax, provided that the share of income received from the sale of these services based on the results of work for the calendar year preceding the calendar year in which the taxpayer submits a notification on the transition to the payment of unified agricultural tax, will be at least $70 \%$.

4. Not entitled to apply the Unified Agricultural Tax: organizations and individual entrepreneurs engaged in the production of excisable goods (with the exception of excisable grapes, wine, sparkling wine (champagne), wine materials, grape must, produced from grapes of the organization's own production), carrying out activities in the field of gambling business, as well as state, budgetary and autonomous institutions.

\section{Results}

The number of peasant (private) households (PFH) for the period from 2006 to 2016 in the Russian Federation decreased from 253.1 thousand to 136.6 thousand, the number of individual entrepreneurs, on the contrary, increased from 32 thousand in 2006 to 38 thousand in 2016. At the same time, the average land area of peasant farms for the specified period more than doubled - from 103 hectares in 2006 to 240.9 hectares in 2016. The land area of individual entrepreneurs also increased - from 106.2 hectares in 2006 to 140 hectares in 2016.

The results of the census also confirmed the fact of an increase in the concentration of agricultural production. According to the data of the All-Russian Agricultural Census, conducted in 2016, over 10 years, the average area of land per one agricultural organization increased by $16.5 \%$, per farm - 2.4 times, and the size of the average plot of land for personal subsidiary plots and other individual households of citizens increased by $39.4 \%$. As a result, $35.0 \%$ of the total sown area in 2016 was managed by enterprises with an area of more than 10 thousand hectares (4.9\% of the total number of agricultural organizations). The presented data testify to the sustainable development of the agrarian sector of the economy of the Russian Federation, and, undoubtedly, one of the tools for this development is precisely the impact of tax levers, which include tax incentives and a special tax regime "Unified Agricultural Tax".

However, for a deeper analysis of the impact of this tax regime on the dynamics of agricultural development in Russia, it is necessary to analyze the data on the formation of the budget of the Russian Federation from special tax regimes, including from the Unified Agricultural Taxation (Figure 1). 


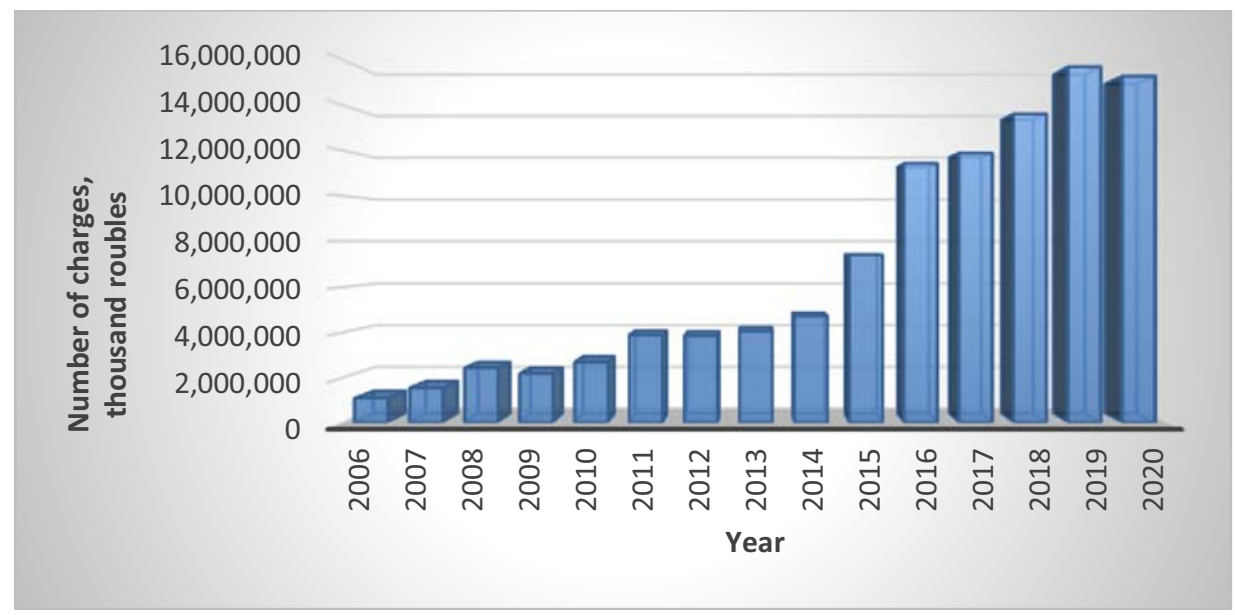

Fig. 1. The amount of tax revenues to the consolidated budget from the payment of unified agricultural tax.

According to the presented statistical data for 2006-2020, we see that the total amount of tax revenues to the consolidated budget from the payment of the unified agricultural tax increased by more than 14 times (in 2006 - 1,072,369 thousand rubles, in 2020 15,294,311) ... However, an analysis of the structure of tax revenues from the unified agricultural tax in the total aggregate of income from special tax regimes to the budget shows that revenues from the unified agricultural tax during the 15 years of the existence of this special regime did not exceed $3 \%$ of the total income to the state budget from special tax regimes, while how revenues from other special tax regimes continue to grow. This, in turn, testifies to the lack of popularity and effectiveness of this regime among agricultural producers in Russia (Figure 2).

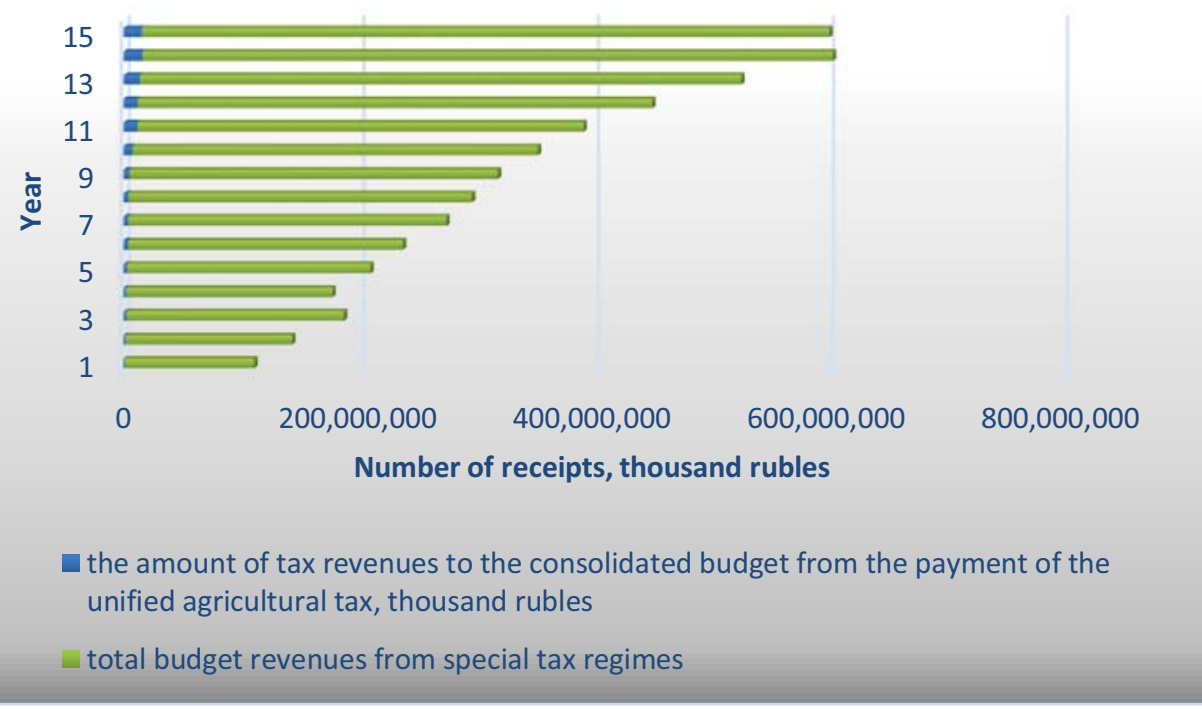

Fig. 2. The structure of tax revenues to the budget of the Russian Federation from special tax regimes. 


\section{Conclusions}

Based on the presented data, it can be concluded that the unified agricultural tax as a preferential tax regime is currently not in high demand by agricultural producers, as evidenced by the presented statistical data (Figure 1,2). Some of the taxpayers employed in agricultural production still prefer to use the simplified taxation system or the patent taxation system. In the general structure of tax revenues from special tax regimes to the state budget, revenues from the single agricultural tax over the 15 years of its existence still did not amount to more than $3 \%$ of the total income. This indicates a flaw in the legislative regulation of this special tax regime. As we can see, even the opportunity provided by the legislator to remain VAT payers for agricultural producers applying this regime since 2019 provided a short-term increase in tax revenues in quantitative terms, however, in the overall structure of income, tax payments from the Unified Agricultural Tax remained at the same volume $(2.6 \%)$.

The conducted studies of the dynamics of the UAT elements allow us to conclude that in order to increase the efficiency of the application of the "single agricultural tax" taxation system, the legislator needs to focus on two aspects: softening the conditions for the application of this tax regime and regional regulation of the UAT elements, which is currently not fully implemented. Least $[8,9,10,11]$. This will allow, on the one hand, to concentrate agricultural producers on the use of this regime, on the other hand, to simplify state regulation of the agricultural sector of the country's economy $[12,13,14,15]$.

\section{References}

1. "Tax Code of the Russian Federation (Part One)" dated July 31, 1998 N 146-FZ (as amended on November 23, 2020) (as amended and supplemented, entered into force on 01.01.2021);

2. "Tax Code of the Russian Federation (part two)" dated 05.08.2000 N 117-FZ (as amended on 17.02.2021)

3. W.M.Liefert, P.C.Westcott, Food Policy, 62, 65-77 (2016) doi.org/10.1016/j.foodpol.2016.04.001

4. X. Wang, Y. Shen, China Economic Review, 29, 185-199 (2014) doi.org/10.1016/j.chieco.2014.04.010

5. J. Jia, S. Ding, Y. Liu, Journal of Urban Economics, 115 (2020) doi.org/10.1016/j.jue.2019.103225

6. M. Coopera, T. Quyen, K. Nguyen, International Business Review, 29 (2020) doi: 10.1016/j.ibusrev.2020.101692

7. Z. Chen, A. Zhang, K. Zhou, L.Huang, Land Use Policy, 100 (2021) doi.org/10.1016/j.landusepol.2020.104860

8. S. Langer, A. Korzhenevych, Land Use Policy, 77, 279-287 (2018) doi.org/10.1016/j.landusepol.2018.05.052

9. B. Lin, Z. Jia, China Economic Review, 56 (2019) doi.org/10.1016/j.chieco.2019.101307

10. Y. Chen, X. Wen, B. Wang, P. Nie, Journal of Cleaner Production, 164, 258-264 (2017), doi.org/10.1016/j.jclepro.2017.06.216

11. R. Zhang, W. Ma, J. Liu, Journal of Cleaner Production, 285 (2021) doi.org/10.1016/j.jclepro.2020.124806 
12. Q. Hong, M. Smart, European Economic Review, 54, 82-95 (2010) doi: 10.1016/j.euroecorev.2009.06.006

13. M. Liu, Z. Xu, F. Su, R. Tao, China Economic Review, 23, 190-203 (2012) doi.org/10.1016/j.chieco.2011.10.002.

14. A. Kato, A. Fukumi, Energy Policy, 145 (2020) doi.org/10.1016/j.enpol.2020.111755

15. R.M. Alexander, A.J.Organ, Business Horizons, 58, 363-369 (2015)

doi.org/10.1016/j.bushor.2015.03.001 